
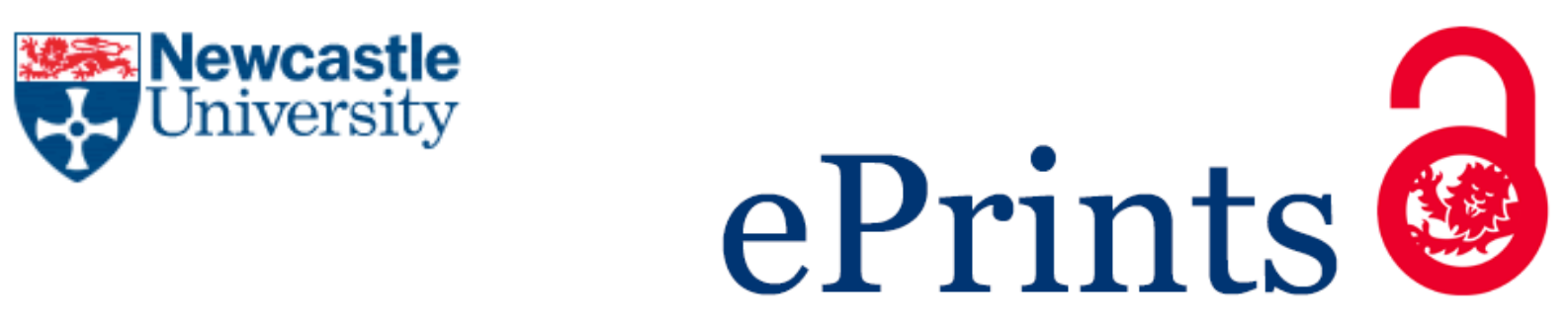

Sicilia M, Steccolini I. Public budgeting in search for an identity: state of the art and future challenges. Public Management Review 2016. DOI: 10.1080/14719037.2016.1243809

\title{
Copyright:
}

This is an Accepted Manuscript of an article published by Taylor \& Francis in Public Management Review on 24 October 2016, available online: http://dx.doi.org/10.1080/14719037.2016.1243809

DOI link to article:

http://dx.doi.org/10.1080/14719037.2016.1243809

Date deposited:

$21 / 12 / 2016$

Embargo release date:

24 April 2018

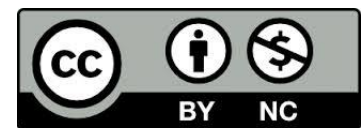

This work is licensed under a Creative Commons Attribution-NonCommercial 3.0 Unported License 


\section{Public budgeting in search for an identity: state of the art and future challenges MariaFrancesca Sicilia, Ileana Steccolini}

Budgeting has traditionally been the process through which governments decide how much to spend on what, limiting expenditures to the revenues available and preventing overspending. Over time public budgets have taken on different roles, becoming tools for bargaining and allocating power, for planning and controlling, for providing impulses to the economic and social environment, and for ensuring transparency and stakeholder involvement (Saliterer et al., forthcoming). As such, budgets play, among others, political, economic, managerial and accountability functions. They perform a political function as they reflect stakeholders' preferences and power positions, representing the same time the result of past decisions and bargains, and the basis for future discussions. They define the boundaries of public intervention in the economy, and the degree of redistribution of wealth in the economic system, fulfilling an economic function. They are also increasingly used to hold managers accountable for the attainment of results and use of public resources, thus filling a managerial function, and to hold public organizations accountable to the general public, satisfying an external accountability function.

The multifaceted nature of budgeting has generally translated into its being the subject of enduring interest by different disciplines, including political science, public administration, accounting, psychology, management, organization studies. At the same time, budgeting is an arena where different rationalities, logics, competencies and professional identities interact. The complexity and variety of functions of budgeting, and its being an arena of interaction of different actors, cultures, professional identities and disciplines probably account for the variety of approaches and forms taken on by budget documents and budgeting processes (Saliterer et al., forthcoming) and by its variable nature over time. These same features also contribute to make public budgeting an extremely fascinating field and topic of investigation, which can provide a number of insights on political, social, economic, psychological processes. It may thus represent the ideal setting for bringing in views from different scholarly communities and disciplines to show what can be learnt by accepting that social, political and economic processes are complex and rich arenas, where deterministic and simplistic explanations limit our views and possibilities, and accepting the challenge of complexity can be risky in the current "publish and perish" culture, but also extremely rewarding and stimulating. 
This is the challenge that the authors of this special issue accepted to take up, contributing to offer a rich and in-depth view of current trends in the studies and practices of public budgeting at a time when NPM influence still appears to remain important (Lapsley, 2009), but claims have increasingly emerged that either other paradigms may be emerging (for example, Osborne, 2006; 2009), or that we may be witnessing a paradigmatic gap (Coen and Roberts, 2012).

A recent review of public budgeting studies in Europe (Anessi et al., 2016) confirms that NPM and modernization movements have significantly influenced the study and practice of public budgeting over the last two decades, showing that most European studies of public budgeting published in the main public administration and accounting journals refer to NPM not only as the context of their analyses, but very often as the main conceptual framework informing them. While this appears to have offered a good opportunity for feeding a debate on managerialism in the public sector, and for accumulating contextual knowledge on public sector reforms, it may have also crowded out scholarly attention from the development of alternative conceptual frameworks. Moreover, far from providing evidence that NPM-type reforms have solved public administration problems, most studies have highlighted that changes in public budgeting, including shifts to performance-based and accruals-based budgeting, are still under way, or their expected benefits are yet to be fully reaped and understood, while a number of unexpected and even undesired effects have arisen.

This suggests that there is an enormous need and scope for exploring budgeting processes in the public sector today, both as a consequence of the managerial waves of reforms that have taken place over the last few decades, and in the light of current emerging trends. The post-crisis and austerity context, the growing inequalities emerging in many countries, the rising emphasis on new forms of service delivery such as coproduction and inter-organizational collaborations, the widespread shift from representative to participative democracy, are among the current trends that may present new challenges for public organizations and the related budgeting processes. In the light of its multifaceted nature, budgeting may be an ideal place to look at the impacts and implications of such trends in the public realm.

Firstly, managerial reforms have suggested the move to an increased reliance on accruals- and performance- based budgets. However, the integration of financial and nonfinancial aspects of performance, and of budgeting and performance management are still underway and not fully understood by scholars. Indeed, an increasing body of literature 
shows that accruals data are not necessarily preferred by either managers or politicians (for a review of relevant literature, see Liguori et al., 2012, 2014), as non-financial performance measures and cash-based data may appeal more to their users' needs. In this respect, some authors suggest that the accruals basis of accounting may be useful for reporting and as an analytical tool, but still may not be needed as a basis for budgeting (Caiden, 2010). Thus, while the literature on the adoption of accruals accounting has become increasingly wide, much less attention has been devoted so far, both in the literature and in practice, to how accruals-based budgeting should work and actually works, or at its impacts for political as well as managerial decision making (for a few notable exceptions, see Ezzamel et al., 2007; Hyndman and Connolly, 2011). Similarly, the role of non-financial performance information in the formulation and execution stages of budgeting goals still remains unclear.

Secondly, austerity and the consequences of the global financial crisis have often caused a re-centralization of budgeting processes (Bracci et al., 2016), while the emergence of increasing complex and non-routine problems to deal with may have generated fragmented decision-making and the need of continuous changes and adjustments to budgets, both in their formulation and in their execution. Practitioners and scholars should devote more attention to requirements of stability and how fiscal rules and constraints, and a search for stability in public finances (macro-budgeting), can go hand in hand, or even require, increased flexibility in budget execution (micro-budgeting).

Thirdly, public management reforms have emphasized the importance of accountability and have promoted transparency and communication of numbers about public organizations. This logic initially has been promoted in a situation in which citizens were mainly viewed as passive actors that receive services and elect their representatives.

With the emergence of ideas of 'active citizenship' and new forms of participatory democracy (Hendriks, 2010), as well as of wider views of co-production as co-planning and co-design (Bovaird, 2007; Sicilia et al., 2016; Barbera et al., 2016) citizens are increasingly seen as active players in public governance, directly involved in deliberations and provisions of services. In the light of such developments, the potential contribution of budgeting to external accountability, both in in term of transparency and communication and in terms of stakeholder involvement and participation requires further investigation.

Fourthly, public service delivery is increasingly requiring the involvement of multiple actors, including other governments or public sector entities, as well as private and nonprofit organizations. Budgeting may play an important role in the distribution and representation 
of resources and responsibilities, as well as in the discharge of accountability in such emerging inter-organizational arrangements. However, its role in inter-organizational relationships has largely been neglected (for example, Marvel and Marvel, 2008; Miller et al., 2008; Cristofoli et al., 2011; Ditillo et al., 2015). This gap needs to be filled through an in-depth analysis of uses and impacts of new tools such as pooled or consolidated budgets, as well as a better understanding of the factors affecting the choice and design of the related practices and processes.

The seven papers of this special issue contribute to fill some of the gaps in the literature on public sector budgeting highlighted above.

Among them, three papers unearth the under-researched relationship among budgeting and performance measurement and management. Mauro, Cinquini and Grossi (this issue) provide a systematic literature review of studies on performance-based budgeting (PBB) published in international academic journals from 1990 to 2014 . The analysis highlights that the majority of such studies are US-based and tend to focus on the description and explanation of implementation issues and obstacles of PBB and the extent and breadth of the use of performance information in budgeting processes. The paper identifies interesting future avenues of research, also advocating the adoption of mixed methods and comparative approaches.

The article by Bleyen et al (this issue) empirically contributes to a better understanding of the phenomenon of incorporation of performance information in budgets by examining and comparing the cases of ten European cities. Performance structures and the dimensions of performance taken into consideration differ significantly across the cases analyzed. This variety can be explained considering varying degrees of reform implementation, experience with PB and prevailing institutional arrangements. However, the paper highlights that a few similarities exists: those municipalities that left the phase of embryonic performance budgeting linked performance information hundred percent to their expenditures; performance objectives are almost always more focused on outcomes and outputs than the underlying performance indicators. This finding suggests similar learning trajectories when performance objectives and indicators are incorporated in the budget.

Drawing on a constructionist approach and applying discourse analysis, the paper of Cuganesan (this issue) seeks to investigate how the design of performance budgeting might shape managerial accountability relationships. Presenting a case study of performance budgeting reforms in the Commonwealth Government of Australia, it reveals that the proposed alternative designs for performance budgeting have shaped the 
managerial accountability relationships in terms of the obligation of actors to inform; forum identity; a forum's ability to discuss and interrogate; and, albeit to a limited extent, potential forum judgements and consequences.

The next four articles offer interesting insights on how budgets respond to contextual features, requests and changes, as they enhance or constrain flexibility in the face of nonroutine problems, uncertainty and shocks, provide tools for strengthening participatory accountability, and can be central in strengthening or hampering a relational or transactional culture in the public realm.

Alford and Di Francesco (this issue) investigate how budget systems can be designed to enable greater situational flexibility while ensuring that public money is managed consistently with the purposes of the government. The authors offer a range of regulatory options for balancing these imperatives of control and flexibility. These options include the leadership/cultural role of central finance agencies in facilitating voluntary rule compliance, performance control, and earned autonomy as a variant of responsive regulation. Whilst each of these options depends crucially on trust building, responsive regulation is seen as a potentially significant change in the practice of budgeting and financial management within government. It assumes that regulators should apply different instruments to regulatees according to their postures toward compliance.

The paper by Ghosh (this issue) investigates if and how the roles of absorbed and unabsorbed slack resources are different in buffering against budgetary shocks. The findings suggest that higher transparency and visibility of slack resources will play a beneficial buffering role against fiscal shock. At the same time, absorbed slack does not seem to provide a meaningful buffer for negative budget shocks.

The paper by Brun-Martos and Lapsley (this issue) tackles with the external accountability role of budgeting. In contributing to fill this gap, the authors examine the experience of participatory budgeting in the city of Edinburgh. They show how participatory budgeting enhances participative democracy and transparency, giving to citizens not only accessibility to information, but also the possibility of participating in a process of construction and sharing of meanings. They also highlight that participatory budgeting acts as a mediating instrument between the two worlds of city management and citizens, forging a bridge across the worlds of management and democratic accountability.

The paper by Wälstedt and Almqvist (this issue) investigates how budgeting can contribute or hamper the diffusion of a relational culture of cooperation, sharing and outcomes-base management advocated in the New Public Governance paradigm. Using a 
constructivist approach to analyse budgeting and control systems in three Swedish municipalities, the authors show that budgeting and its reinforcement of traditional and transactional systems makes it difficult to employ relational approaches in practice.

The papers included in this special issue represent yet another pillar in the accumulation of knowledge on public sector budgeting. They address a number of critical issues on this broad topic, offering new perspectives on current evolutions in public budgeting, but also showing that public budgeting can and must remain the subject of enduring interest in our studies and thus opening new possibilities of research. We hope that this special issue, far from being a closure, will represent an opening of further future debates, reflections and studies on this topic. 


\section{References}

Anessi Pessina E., C. Barbera, M. Sicilia and I. Steccolini. 2016. "Public sector budgeting: A European review of accounting and public-management journals." Accounting, Auditing and Accountability Journal 29 (3): 491 - 519.

Barbera C., M. Sicilia and I. Steccolini. 2016. "What Mr. Rossi Wants in Participatory Budgeting: Two Rs (Responsiveness and Representation) and Two Is (Inclusiveness and Interaction)." International Journal of Public Administration, DOI: 10.1080/01900692.2016.1177839

Bovaird T. 2007. "Beyond Engagement and Participation: User and Community Coproduction of Public Services." Public Administration Review 67(5): 846-860.

Bracci, E., C. Humphrey, J. Moll and I. Steccolini. 2015. "Public sector accounting, accountability and austerity: more than balancing the books?." Accounting, Auditing \& Accountability Journal 28 (6): 878 - 908.

Caiden, N. 2010. "Challenges confronting contemporary public budgeting: retrospectives/prospectives from Allen Schick." Public Administration Review 70 (2): 203210.

Coen D. and A. Roberts. 2012. "A New Age of Uncertainty". Governance, 25 (1): 5-9.

Cristofoli D., A. Ditillo, M. Liguori, M. Sicilia and I. Steccolini. 2010. "Do environmental and task characteristics matter in the control of externalized public services? Unveiling the relevance of party characteristics and citizens' offstage voice?." Accounting, Auditing \& Accountability Journal 23 (3): 350-372.

Ditillo A., M. Liguori, M. Sicilia and I. Steccolini. 2014. "Control patterns in hybrid relationships: it matters what you do, not who you are." Public Administration 93 (1): 212229.

Ezzamel, M., N. Hyndman, A. Johnsen, I. Lapsley, and J. Pallot. 2007. "Experiencing institutionalization: the development of new budgets in the UK devolved bodies". Accounting, Auditing and Accountability Journal 20 (1): 11-40.

Hendriks, F. 2010. Vital democracy: a theory of democracy in action. Oxford: Oxford University Press.

Hyndman, N. and C. Connolly. 2011. "Accruals accounting in the public sector: a road not always taken". Management Accounting Research 22 (1): 36-45.

Lapsley, I. 2009. "New Public Management: The Cruellest Invention of the Human Spirit?" Abacus 45 (1): 1-21.

Liguori M., M. Sicilia and I. Steccolini. 2014. "Public value as "performance": politicians' and managers' perspectives on the importance of budgetary, accruals and non-financial measures." In Public Value and Performance Management, Measurement and Reporting Studies in Public and Non-Profit Governance, Volume 3, edited by J. Guthrie, G. Marcon, S. Russo and F. Farneti, 85-104. Emerald.

Liguori, M., M. Sicilia, and I. Steccolini. 2012. "Some like it non-financial... politicians' and managers' views on the importance of performance information". Public Management Review 14 (7): 903-922.

Marvel M. and H. Marvel. 2007. "Outsourcing Oversight: A Comparison of Monitoring for In-House and Contracted Services". Public Administration Review 67 (3), 521-530. 
Miller, P., L. Kurunmäki and T. O'Leary. 2008. "Accounting, hybrids and the management of risk" Accounting, Organizations and Society 33 (7/8): 942-967.

Osborne S. P. 2006. "The New Public Governance?”. Public Management Review 8 (3): 377-387.

Osborne, S. P. 2009. "Delivering Public Services: Are We Asking the Right Questions?" .Public Money \& Management 29 (1): 5-7.

Saliterer I., Sicilia M., Steccolini I. (forthcoming), "Public budgets and budgeting: state of the art and future challenges". In Handbook of Public Administration and Management in Europe, edited by E. Ongaro E. and S. Van Thiel S. Palgrave.

Sicilia M, E. Guarini, A. Sancino, M. Andreani and R. Ruffini. 2016. "Public Service management and co-production in multi-level governance settings". International Review of Administrative Science 82(1): 8-27. 